\title{
Ex vitro Performance and Genetic Stability of Strawberry Plants Derived from Different in Vitro Propagation Methods
}

\author{
Fouad H. Mohamed, Khalid E. Abd El-Hamed, Farouk A. Omar, Abdallah A. El-Shahat \\ Department of Horticulture, Faculty of Agriculture, Suez Canal University, Egypt 41522
}

Received: 10/5/2017

\begin{abstract}
Ex vitro experiment was conducted at the greenhouse and nursery facilities of the Plant Tissue Culture Laboratory of Department of Horticulture, Faculty of Agriculture, Suez Canal University during the period 2009-2012. Strawberry ex vitro growth performance of tissue culture-derived plants from different propagation methods (meristem, direct regeneration and callus-derived plants) were examined with standard runner-propagated mother plants based on morphological traits and genetic analysis using RAPD. Ex vitro growth performance examination showed that leaf morphology and serration patterns were almost similar among plants obtained from meristem, direct or callus regeneration. Tissue culture plants have higher number of runners while standard runner plants were higher in flower production compared with in vitro propagated plants. RAPD analysis indicated that plants of cv. 'Tudla' from the different in vitro propagation methods were genetically stable, while in cv. 'Festival', callus-derived plants deviated from normal genotype. The obtained results confirmed the usefulness of RAPD in determining genetic stability of plants clonally propagated in vitro as well as detecting the somaclonal variants, which might be used further in breeding programs.
\end{abstract}

Keywords: Fragaria x ananassa Duch, Tissue Culture, RAPD, Genotypes, Adventitious Regeneration

\section{INTRODUCTION}

Strawberry is becoming one of the major crops in Egypt for fresh fruit consumption, processing, and export. In 2013, the cultivated area reached 6029 ha, with total production of 254,921 tons and average yield of 46.6 ton/ha (FAOSTAT, 2015). This expansion requires the availability of pathogen-free transplants, depending on the introduction of modern micropropagation systems. Traditionally, strawberry plants are propagated by runners derived from nuclear stock materials via shoot meristem tip culture in vitro (Boxus, 1974). For breeding purposes, plants could be obtained indirectly via callus culture phase, or directly from leaf disc explants (Mohamed et al., 2007). Under certain conditions, both in vitro propagation systems allow the production of variant plants, of which some might show unique characteristics as new somaclones. However, plants derived from these propagation systems were not widely examined for their ex vitro performance.

In strawberry, meristem culture is a widely used technique for virus elimination, mass propagation and germplasm preservation (Boxus et al., 1977; Kartha et al., 1980). However, the excision of meristems is time consuming and requires technical skill. It is also difficult to utilize meristem culture for genetic transformation. As an alternative, the high frequency direct shoot regeneration from leaf discs which avoids an intervening callus phase and thus minimize the risk of genetic instability was suggested (Nehra et al., 1989; Mohamed et al., 2007). The availability of these diverse plant regeneration protocols in strawberry now provides an opportunity for comparative field evaluation of plants obtained from different tissue culture methods. Thus far, field trials of in vitro-propagated strawberry have concentrated on comparing meristem-propagated plants with conventional runner plants in different genotypes (Swartz et al., 1981; Marcotrigiano et al., 1984; Cameron et al., 1985; Mohamed et al., 1991;

Corresponding author e-mail: khalidegy1@yahoo.com
Gaafar and Saker, 2006). Strawberry plants derived from shoot tip culture have been reported to show changes in growth habit, runner production and other vegetative and sexual characters (Debnath, 2009; Cameron and Hancock, 1986; Swartz et al., 1981). Szczygiel et al. (2002) reported that the effect of micropropagation on fruit yield and quality was usually smaller than on reproduction rate and was limited mainly to plantlets coming directly from micropropagation. Karhu and Hakala (2002) suggested that the micropropagated plants of the cultivars studied can crop well and grow without large, undesirable alterations in flowering or in growth habit. Litwińczuk (2004) concluded that the most visible and year-stable aftermath of micropropagation was hyper-flowering caused by increased number of inflorescences. The hyper-flowering is unlikely to be caused by true mutations, but to DNA methylation (Boxus et al., 2000).

At the molecular level, variations in tissue culture-derived plants arise from changes in chromosome number or structure, or from more slight changes in the DNA (Gostimsky et al., 2005). Visible morphological variation is known to occur at a much lower frequency than at the DNA level (Evans et al., 1984; Evans, 1989). As a result, it is necessary to examine for potential variation at the molecular level in order to determine locations and extent of deviance from the true-to-type clone plant (Cloutier and Landry, 1994).

Besides providing an efficient technique for polymorphism that allows rapid identification and isolation of chromosome-specific DNA fragments, Random Amplified Polymorphic DNA (RAPD) markers are also useful for genetic mapping, DNA fingerprinting, and plant breeding (Venkatachalam et al., 2008). The use of RAPD markers are especially beneficial to discriminate between materials that are genetically similar, to evaluate genetic variability within a collection and to choose the components of the core collection (Piola et al., 1999; Bernardo Royo and Itoiz, 
2004). Furthermore, some authors have found RAPD techniques useful in examining tissue culture-induced variation in strawberry (Gaafar and Saker, 2006; Mohamed, 2007). However, their studies were only limited to the detection of variations among shoot meristem-derived plants and those of conventional runner-propagated plants.

Identically banding patterns of the RAPD profiles obtained from in vitro plants, regenerated through organogenesis (leaf or petiole) or meristem tip culture suggest that different tissue culture methods were not associated with occurrence of somaclonal variation in the ornamental strawberry (Sutan et al., 2009). Similar results have been found in meristem tip culture of three strawberry cultivars analyzed by RAPD-PCR (Mohamed, 2007). Moreover, although minor morphological variations have been recorded in strawberry leaves, the RAPD profiles of different micropropagated clones were typical to that of the donor mother plants (Gaafar and Saker, 2006). Kumar et al., (1999) used RAPD markers to determine if cold storage or supra-optimal levels of BA in the culture medium can cause genetic changes leading to somaclonal variation in strawberry and the low level of RAPD variation observed, along with the apparent epigenetic changes in morphological characteristics demonstrated that no mutations had occurred.

Recently, Genetic evaluation via ISSR showed no polymorphism in banding pattern which indicates no significant variation between strawberry micropropagated and conventionally propagated plants at the molecular level (Sharma and Kumar, 2012; Gantait et al., 2010; Sen and Dhawan, 2010). On the other hand, Biswas et al. (2009) were able to correlate phenotypic variation resulting from regeneration using different tissue culture techniques (meristem, direct organogenesis from leaf, regeneration from callus culture, somatic embryogenesis) with alterations in the DNA banding pattern using RAPD. Besides, the RAPD technique was used for assessing genetic variation and relationship among 18 tissue culture variants of strawberry and the results indicated that the variants were genetically different from each other (Haque, 2013).

The objectives of the present investigation were to examine morphological and growth characters of strawberry plants derived from different in vitro propagation methods, and to monitor genetic stability of tissue culture-derived plants using RAPD-PCR technique.

\section{MATERIALS AND METHODS}

The following experiment was conducted at the Plant Tissue Culture Laboratory and the greenhouse facilities of the Department of Horticulture, Faculty of Agriculture, Suez Canal University, Egypt during the period 2009-2012. Ex vitro performances of tissue culture-derived strawberry plants from different genotypes 'Tudla', 'Festival', 'Galexia' and 'Camarosa' and propagation methods (shoot meristem proliferation, direct shoot regeneration and callus- derived plants) were examined with standard runner-propagated cold stored transplants along with testing the genetic stability of these plants using RAPD-PCR.

\section{Ex vitro performance during acclimatization}

The proliferated cultures from meristem, callus or direct regeneration from previous in vitro experiment (Mohamed et al., 2013) were transferred into rooting medium composed of MS salts (Murashige and Skoog, 1962) plus $0.5 \mathrm{mg} / \mathrm{l} \mathrm{IBA}$ in $200 \mathrm{ml}$ jam jars amended with $30 \mathrm{ml}$ medium for 45 days. Rooted cultures from each cultivar and propagation method were isolated from the culture jars, washed thoroughly in running tap water to remove any remaining of agar from the medium. Plantlets were moved to the greenhouse for acclimatization in $5 \mathrm{~cm}$ plastic pots containing soilless medium (peat moss + vermiculite $1: 1$ by volume), covered with plastic sheet and mist irrigated daily for a period of two weeks. Misting intervals were gradually decreased until plantlets were fully acclimatized after 8 weeks. Plants were sub-cultured into larger plastic pots (15 $\mathrm{cm})$ containing peat moss and sand (1/1 by volume) and allowed to grow in the greenhouse.

Leaf morphology and growth habit of plants from the different in vitro propagation methods were examined by testing the following parameters after 8 10 weeks from acclimatization: leaf width (W), leaflet length (middle leaflet) (L), ratio of W/L. Leaf serration pattern: number of teeth in the right, middle and left leaflet in a leaf.

Plants were then allowed to grow further in larger $(20 \mathrm{~cm})$ plastic pots, irrigated and fertilized biweekly using $19 \quad-19 \quad-19$ NPK nutrient solution (1-2 g/l). Growth and flowering were examined after 2 months in each propagation methods and cultivar as follow: number of leaves/plant, number of branch crowns /plant, number of runners /plant, number of daughter plants/ plant, number of flower clusters / plant, and number of flowers /cluster.

\section{Statistical Analysis}

All recorded data were analyzed using ANOVA with mean values compared using Duncan's multiple range with a significance level of $5 \%(p=0.05)$ (Steel and Torrie, 1980).

\section{RAPD-PCR analysis}

Genomic DNA isolation : DNA of three strawberry cultivars from different in vitro propagation methods (meristem, direct and callus) and from runnerpropagated plants (RP) was extracted from the leaves of greenhouse-grown, fully acclimatized plants of the cultivars 'Tudla', 'Galexia' and 'Festival' following the method of Murray and Thompson (1980). Small pieces $(0.5 \mathrm{~g})$ of leaf tissue were frozen in liquid nitrogen in Eppendorf tubes and homogenized in $500 \mathrm{ml}$ of extraction buffer $(2 \%$ CTAB, $1.4 \mathrm{~m} \mathrm{NaCl}, 20 \mathrm{mM}$ EDTA pH 8.0, 100 mMTris-HCl, pH 8.0, $0.1 \mathrm{~m}$ BMercato ethanol). The extract was incubated at $60 \mathrm{C}^{\circ}$ for $20 \mathrm{~min}$. To this, $500 \mathrm{ml}$ of phenol : chloroform : isoamyl alcohol (24:24:1) were added and mixed by vortexing for $30 \mathrm{sec}$. followed by centrifugation at $10,000 \mathrm{~g}$ for $5 \mathrm{~min}$. at room temperature.

The aqueous phase was transferred to another tube. This was once again extracted with $500 \mathrm{ml}$ of 
chloroform: isoamyl alcohol (24:1) in Eppendorf tubes. To the aqueous phase, 0.6 volume of isopropanol were added, precipitated the genomic DNA and spooled the fibrous DNA. Genomic DNA was then washed three times with $70 \%$ ethanol, dried in vacuum, dissolved in TE containing $10 \mathrm{mg} / \mathrm{ml}$ RNase and incubated at $37 \mathrm{C}^{\mathrm{o}}$ for $30 \mathrm{~min}$. followed by extraction with phenal: chloroform: isoamyl alcohol and the aqueous phase was transferred to a fresh tube. The genomic DNA was then precipitated by adding $0.3 \mathrm{M}$ sodium acetate, $\mathrm{pH} 5.2$ (final concentration) and 2.5 vol. of ethanol and collected by centrifugation at $10.000 \mathrm{x}$ g for $20 \mathrm{~min}$. at $4^{\circ} \mathrm{C}$. The pellet was washed with $70 \%$ ethanol, vacuum dried and dissolved in TE.

Ten random oligonucleotide (10 mer) primers were tested for use in RAPD analysis. Theprimerswere (OPO 11- OPA 12- OPA 13- OPA 14- OPA 15- OPA 16- OPA 17- OPA 18- OPA 19- OPA 20) (OperonTechnology Inc., Alameda, California) (Table 1).

Table (1): The nucleotide sequence of primers used in RAPD analysis

\begin{tabular}{ccc}
\hline & Primer & Nucleotide Sequence \\
\hline 1 & OPO 11 & 5'GACAGGAGGT3' \\
2 & OPA 12 & 5'TCGGCGATAG3' \\
3 & OPA 13 & 5'CAGCACCCAC3' \\
4 & OPA 14 & 5'TCTGTGCTGG3' \\
5 & OPA 15 & 5'TTCCGAACCC3' \\
6 & OPA 16 & 5'AGCCAGCGAA3' \\
7 & OPA 17 & 5'GACCGCTTGT3' \\
8 & OPA 18 & 5'AGGTGACCGT3' \\
9 & OPA 19 & 5'CAAACGTCGG3' \\
10 & OPA 20 & 5'GTTGCGATCC3' \\
\hline
\end{tabular}

The PCR reactions were carried out in $50 \mu \mathrm{L}$ volume tubes containing $100 \mathrm{ng}$ of genomic DNA, 10 $\mu \mathrm{M}$ of each primer, $200 \mu \mathrm{M}$ of dATP, dDTP, dCTP, dGTP, 10 mMTris-HCL, $\mathrm{pH} 8.3,50 \mathrm{mM} \mathrm{MgCl}_{2}$ and $0.001 \%$ gelatin. The Taq DNA polymerase (Promega, Corporation, Madison, WI) concentration was 1.5 units per assay. The PCR reaction was conducted using Eppendorf thermo cycler programmed according to the following protocol that consisted of $1 \mathrm{~min}$. at $95 \mathrm{C}^{\mathrm{o}}$ followed by 55 cycles of $20 \mathrm{sec}$. at $94^{\circ} \mathrm{C}, 30 \mathrm{sec}$. at 37 ${ }^{\circ} \mathrm{C}$, and 2 min. at $72{ }^{\circ} \mathrm{C}$ as described by Nadig et al. (1998). Amplification products were electrophoresed in $1.5 \%$ Agarose gel in $1 \mathrm{x}$ TAE buffer, stained with ethidium bromide and visualized with UV transilluminator and photographed. A $100 \mathrm{bp}$ DNA ladder of $1000 \mathrm{bp}$ (Promega, Corporation, Madison, WI) was used as a standard for primers OPO 11 and OPA 12, while for primer OPA 13, a 100 bp DNA marker with 11 bands (from $100-1500$ bp) was used (Gene on, UK).

\section{RESULTS}

\section{Ex vitro leaf morphology in plants from different propagation methods}

Leaf growth measurements, including leaf width (W), middle leaflet length (L) were measured to estimate the leaf width/leaf length ratio as indicator of variation from normal leaf morphology. Results in Table (2) showed little differences in leaf W among the different propagation methods in cvs. 'Galexia' and 'Camarosa', but in cv. 'Tudla', meristem-derived plants had less leaf W. In cv. 'Festival' and 'Galexia', direct regenerated plants had the least leaf $\mathrm{W}$ compared to RP plants. In cv. 'Galexia', plants from invitro regeneration had higher leaf $\mathrm{L}$ than RP plants, in contrast to $\mathrm{cv}$. 'Festival'. Callus-derived plants of cvs. 'Tudla' and 'Camarosa' had higher leaf $\mathrm{L}$ than the other propagation methods. Significant differences in central leaflet L/W were also detected among the different propagation methods. In cv. 'Galexia', leaves from direct regeneration had less leaf $\mathrm{W} / \mathrm{L}$ ratio (1.48) than those derived from callus, meristem and RP plants which showed almost similar $\mathrm{W} / \mathrm{L}$ ratio. In the rest of cultivars under investigation in the greenhouse ('Tudla', 'Festival', and 'Camarosa'), leaf $\mathrm{W} / \mathrm{L}$ ratio was the same (approximately $1.6-1.8$ ) among the different in vitro propagation methods (meristem, direct and indirect callus regeneration) as those of mother RP plants. Observation on serration patterns i.e.; teeth morphology and numbers in the middle, right and left leaflet of complete leaves from the different propagation methods and cultivars were taken as indicator for deviation from normal phenotype. In cv. 'Galexia', number of teeth in the three leaflets derived from meristem- propagated plants was similar to RP plants (Table 2) and ranged from 13.3 to 14.3 . These numbers declined only by one tooth in callus and direct regenerated plant leaves (between 12.3 -13.0). In cv. 'Tudla', number of teeth in the three leaflets of callus and meristem-derived plants were similar in the right, left and middle leaflets, but less than those derived from direct or RP plants. For the cv. 'Festival', number of teeth of RP plants was high (17 -19) compared to meristem plants (14-16) and much lower in callus regenerated plants $(10-11.3$ tooth /leaflet). However, there was kind of similarity between right and left leaflets in number of teeth which were higher than in the middle leaflet. The above trend was almost true for the leaf serration pattern of $\mathrm{cv}$. 'Camarosa' (Table 2). In most cvs., the ratio between number of teeth of the right, middle and left leaflets were almost 1:1:1 for each propagation methods in a certain cultivar, indicating no deviation in serration patterns among the different propagation methods under investigation.

In this study, fully acclimatized plants derived from RP, meristem, callus and direct shoot regeneration in vitro were transferred into larger plastic pots for further growth. Branching pattern (leaf, runner, branch crown and daughter plant numbers/plant) and flowering were measured for each propagation method (Table 3 ). Number of leaves per crown in cv. 'Galexia' ranged from 7.0 in RP plants to 8.7 in direct regenerates, and 
Table (2): Morphological characteristics of strawberry leaves derived from different in vitro propagation method

\begin{tabular}{|c|c|c|c|c|c|c|c|}
\hline \multirow{2}{*}{ CVs. } & \multirow{2}{*}{$\begin{array}{l}\text { Propagation } \\
\text { Method }\end{array}$} & \multirow{2}{*}{$\begin{array}{c}\text { Leaf Width } \\
\text { (cm) } \\
\text { (W) }\end{array}$} & \multirow{2}{*}{$\begin{array}{l}\text { Middle Leaflet } \\
\text { Length (cm) } \\
\text { (L) }\end{array}$} & \multirow{2}{*}{$\begin{array}{l}\text { W/L } \\
\text { Ratio }\end{array}$} & \multicolumn{3}{|c|}{ Teeth Number /Leaflet } \\
\hline & & & & & Right & Middle & Left \\
\hline \multirow[t]{4}{*}{ Tudla } & $\mathbf{R} \mathbf{P}^{*}$ & $6.1 \mathrm{ab}^{* * *}$ & $3.57 \mathrm{ab}$ & 1.70 & $18.6 \mathrm{a}$ & $18.6 \mathrm{a}$ & $18.0 \mathrm{a}$ \\
\hline & Meristem & $5.4 b$ & $3.14 \mathrm{~b}$ & 1.72 & $13.0 \mathrm{c}$ & $13.0 \mathrm{c}$ & $12.0 \mathrm{c}$ \\
\hline & Direct & $6.0 \mathrm{ab}$ & $3.27 \mathrm{~b}$ & 1.84 & $15.6 b$ & $15.6 b$ & $16.0 \mathrm{~b}$ \\
\hline & Callus & $6.9 \mathrm{a}$ & $4.07 \mathrm{a}$ & 1.70 & $13.3 \mathrm{c}$ & $13.3 \mathrm{c}$ & $12.3 \mathrm{c}$ \\
\hline \multirow[t]{4}{*}{ Festival } & $\mathbf{R P}$ & $10.2 \mathrm{a}$ & $5.87 \mathrm{a}$ & 1.74 & $19.0 \mathrm{a}$ & $19.0 \mathrm{a}$ & $18.6 \mathrm{a}$ \\
\hline & Meristem & 7.04ab & $4.4 b$ & 1.60 & $16.3 b$ & $16.3 b$ & $16.6 b$ \\
\hline & Direct & $5.2 b$ & $3.0 \mathrm{bc}$ & 1.73 & $17.3 b$ & $17.3 b$ & $19.0 \mathrm{a}$ \\
\hline & Callus & $5.95 b$ & $3.54 \mathrm{bc}$ & 1.68 & $11.3 \mathrm{c}$ & $11.3 \mathrm{c}$ & $11.0 \mathrm{c}$ \\
\hline \multirow[t]{4}{*}{ Galexia } & $\mathbf{R P}$ & $7.14 \mathrm{ab}$ & $3.97 b$ & 1.79 & $14.3 \mathrm{a}$ & $14.3 \mathrm{a}$ & $14.0 \mathrm{a}$ \\
\hline & Meristem & $8.07 \mathrm{a}$ & $4.94 \mathrm{a}$ & 1.63 & $14.3 \mathrm{a}$ & $14.3 \mathrm{a}$ & $13.3 \mathrm{~b}$ \\
\hline & Direct & $6.9 \mathrm{ab}$ & $4.67 \mathrm{a}$ & 1.48 & $13.0 \mathrm{~b}$ & $13.0 \mathrm{~b}$ & $13.0 \mathrm{~b}$ \\
\hline & Callus & $6.97 \mathrm{ab}$ & $4.30 \mathrm{ab}$ & 1.62 & $13.0 \mathrm{~b}$ & $13.0 \mathrm{~b}$ & $12.6 \mathrm{bc}$ \\
\hline \multirow[t]{4}{*}{ Camarosa } & $\mathbf{R P}$ & $7.4 \mathrm{a}$ & $4.04 \mathrm{ab}$ & 1.83 & $13.3 \mathrm{a}$ & $13.3 \mathrm{a}$ & $13.0 \mathrm{a}$ \\
\hline & Meristem & $7.07 \mathrm{a}$ & $4.27 \mathrm{a}$ & 1.66 & $12.6 \mathrm{ab}$ & $12.6 \mathrm{ab}$ & $12.3 b$ \\
\hline & Direct & $6.3 \mathrm{ab}$ & $3.77 b$ & 1.67 & $13.0 \mathrm{a}$ & $13.0 \mathrm{a}$ & $13.3 \mathrm{a}$ \\
\hline & Callus & $7.5 \mathrm{a}$ & $4.37 \mathrm{a}$ & 1.72 & $12.0 \mathrm{~b}$ & $12.0 \mathrm{~b}$ & $12.3 \mathrm{~b}$ \\
\hline \multicolumn{8}{|c|}{$\begin{array}{l}{ }_{* *}^{*}=\text { Runner Propagated } \\
=\text { For each cultivar, means }\end{array}$} \\
\hline $\mathrm{CV}$. & $\begin{array}{l}\text { Propagation } \\
\text { Method }\end{array}$ & $\begin{array}{c}\text { Leaf/Crown } \\
\text { No. }\end{array}$ & $\begin{array}{c}\text { Branch } \\
\text { Crown } \\
\text { No. }\end{array}$ & $\begin{array}{c}\text { Daughter } \\
\text { Plant } \\
\text { No. } \\
\end{array}$ & $\begin{array}{c}\text { Runner } \\
\text { No. }\end{array}$ & $\begin{array}{c}\text { Flower } \\
\text { Cluster } \\
\text { No. }\end{array}$ & $\begin{array}{c}\text { Flower/ } \\
\text { Cluster } \\
\text { No. }\end{array}$ \\
\hline \multirow{4}{*}{ Tudla } & $\mathbf{R} \mathbf{P}^{*}$ & $7.8 b^{* *}$ & $0.2 b$ & $1.66 \mathrm{bc}$ & $1.0 \mathrm{c}$ & $1.25 \mathrm{a}$ & $5.5 \mathrm{a}$ \\
\hline & Meristem & $5.9 \mathrm{c}$ & $0.0 \mathrm{c}$ & $2.16 \mathrm{~b}$ & $2.16 \mathrm{~b}$ & $1.0 \mathrm{a}$ & $4.0 \mathrm{~b}$ \\
\hline & Direct & $10.4 \mathrm{a}$ & $1.0 \mathrm{a}$ & $3.33 \mathrm{ab}$ & $3.0 \mathrm{a}$ & $0.0 \mathrm{~b}$ & $0.0 \mathrm{c}$ \\
\hline & Callus & $9.0 \mathrm{ab}$ & $0.0 \mathrm{c}$ & $4.0 \mathrm{a}$ & $2.0 \mathrm{~b}$ & $0.0 \mathrm{~b}$ & $0.0 \mathrm{c}$ \\
\hline \multirow{4}{*}{ Festival } & $\mathbf{R P}$ & $8.0 \mathrm{c}$ & $0.0 \mathrm{c}$ & $0.0 \mathrm{c}$ & $0.0 \mathrm{~b}$ & $1.33 \mathrm{a}$ & $6.33 \mathrm{a}$ \\
\hline & Meristem & $10.0 \mathrm{a}$ & $0.25 b$ & $8.2 b$ & $4.2 \mathrm{a}$ & $0.0 \mathrm{~b}$ & $0.0 \mathrm{c}$ \\
\hline & Direct & $9.7 \mathrm{a}$ & $0.40 \mathrm{a}$ & $6.33 a$ & $3.83 \mathrm{a}$ & $1.33 \mathrm{a}$ & $5.6 \mathrm{ab}$ \\
\hline & Callus & $9.2 \mathrm{ab}$ & $0.20 \mathrm{~b}$ & $6.57 b$ & $3.71 \mathrm{a}$ & $1.33 \mathrm{a}$ & $4.6 b$ \\
\hline \multirow{4}{*}{ Galexia } & $\mathbf{R P}$ & $7.0 \mathrm{~b}$ & $0.2 \mathrm{c}$ & $1.5 \mathrm{~cd}$ & $1.5 \mathrm{bc}$ & $1.0 \mathrm{a}$ & $4.6 \mathrm{a}$ \\
\hline & Meristem & $4.4 \mathrm{c}$ & $0.0 \mathrm{c}$ & $4.0 \mathrm{~b}$ & $2.0 \mathrm{~b}$ & $0.0 \mathrm{~b}$ & $0.0 \mathrm{~b}$ \\
\hline & Direct & $8.7 \mathrm{a}$ & $1.2 \mathrm{a}$ & $2.6 \mathrm{c}$ & $1.8 b$ & $1.0 \mathrm{a}$ & $4.0 \mathrm{a}$ \\
\hline & Callus & $9.2 \mathrm{a}$ & $0.6 b$ & $6.5 \mathrm{a}$ & $3.7 \mathrm{a}$ & $0.0 \mathrm{~b}$ & $0.0 \mathrm{~b}$ \\
\hline \multirow{4}{*}{ Camarosa } & $\mathbf{R P}$ & $8.44 b$ & $0.22 \mathrm{a}$ & $2.0 \mathrm{~b}$ & $2.0 \mathrm{~b}$ & $1.66 \mathrm{ab}$ & $6.0 \mathrm{a}$ \\
\hline & Meristem & $8.8 \mathrm{ab}$ & $0.0 \mathrm{~b}$ & $6.3 \mathrm{a}$ & $4.66 a$ & $0.0 \mathrm{~b}$ & $0.0 \mathrm{c}$ \\
\hline & Direct & $9.16 \mathrm{a}$ & $0.25 \mathrm{a}$ & $2.5 b$ & $1.8 b$ & $2.0 \mathrm{a}$ & $5.0 \mathrm{~b}$ \\
\hline & Callus & $8.2 b$ & $0.2 \mathrm{a}$ & $3.0 \mathrm{~b}$ & $2.6 \mathrm{~b}$ & $0.0 \mathrm{~b}$ & $0.0 \mathrm{c}$ \\
\hline
\end{tabular}

PR= Runner Propagated

$* * *=$ For each cultivar, means followed by the same letter (s) in each column are not significantly different at $(p \leq 5 \%)$. 
9.2 leave/crown in callus-derived plants, but was less in meristem-propagated plants (ave. 4.4 leaves /crown). The same trend was true in cv. 'Tudla'. However, in cvs. 'Festival' and 'Camarosa', number of leaves per crown among different propagation methods was almost the same (between 8.0 and 10 leaves/ crown) as shown in (Table 3).

Strawberry cultivars from different propagation methods did not form countable number of side crowns. In all cvs., meristem-derived plants did not induce branch crowns except cv. 'Festival'. In cv. 'Galexia', direct regenerated plants had the largest branch crown number per plant (ave. 1.2) compared to callus-derived plants ( 0.6 crown) and RP plants ( 0.2 crowns). Similar trend was observed in cvs. 'Tudla' and 'Festival', where their direct- regenerated plants had more branch crowns than plants of other propagation methods. In cv. 'Camarosa', the number of branch crowns/ plant were similar in RP, callus and direct- regenerated plants.

Differences among different propagation methods were observed in number of runners produced per plant. In cvs. 'Festival' and 'Camarosa', meristem derived plants had more runners (4.2-4.66) than the rest of other propagation methods, while in cv. 'Galexia', callus-regenerated plants had more runners (3.7 runner/plant) than $\mathrm{RP}$, direct and meristem- propagated plants. The average number of runners per plant was almost equal in meristem, callus and direct regenerated plants as tested over the four cultivars in this study (ave. 4.0 runners per plant per propagation methods) and more than RP plants.

Meristem and callus-propagated plants produced runner with more daughter plants per plant (ave. 5.0 daughter plants/plant) than direct regenerated plants (ave. 3.7 per plant) and much more than RP plant (ave. 1.3 daughter /plant) as tested over the four cultivars. In the cvs. 'Festival' and 'Camarosa', meristem-derived plants had more daughter plants than the other propagation methods (between 6.3 to 8.2 daughter plants per plant), while for the cvs. 'Galexia' and 'Tudla', callus-derived plants produced more daughters than meristem, direct and RP plants as shown in Table (3).

Meristem derived plants of cvs. 'Galexia', 'Festival' and 'Camarosa' did not initiate flowers. Also, callus- derived plants of cvs. 'Galexia', 'Tudla' and 'Camarosa' did not produce flowers, while callus derived plants of cv. Festival produced an average 1.3 flower clusters bearing an average of 4.6 flowers per plant (Table 3). Direct regenerated plants of cvs. 'Galexia' and 'Camarosa' had more flowers/cluster and flowers per plant than callus or meristem- derived plants. In general, RP plants were the most to produce flowers compared to in vitro propagated plants.

\section{Genetic stability of tissue culture derived plants}

In this study, four kinds of plant materials were tested for genetic stability including in vitro-derived plants from meristem, direct and callus regeneration, in addition to runner propagated (RP) plants. DNAs of these materials were extracted and compared by RAPD - PCR using random oligonucletide primers. Of the ten primers used, three successfully yielded bands across the tested cultivars and propagation methods (OPO 11, OPA 12 and OPA 13). For computer analysis of banding patterns, intensive bands were considered as present (1) while weak or absent bands were considered as absent (0). Tables (4) and (5) and Figure (1) show the reaction of the three primers (OPO 11, OPA 12, OPA13) with the four different propagation methods in the cvs. 'Tudla', 'Galexia' and 'Festival'.

In cv. 'Tudla', all the three primers yielded 68 different bands (Table 4 ) with size ranged from $83 \mathrm{bp}$ to $1780 \mathrm{bp}$ (26 for OPO11, 12 for OPA12 and 30 for OPA13). Out of them, 10 bands were polymorphic, ranged in size from $83 \mathrm{bp}$ to $1257 \mathrm{bp}$. The percentages of polymorphism were $15.39 \%(4 / 26)$ for OPO 11 , $33.33 \%(4 / 12)$ for OPA12 and $6.67 \%(2 / 30)$ for OPA13 (Table 5). In cv. 'Galexia', the three primers yielded 60 bands (Table 4) with size ranged from $66 \mathrm{bp}$ to $1780 \mathrm{bp}$ (23 for OPO11, 12 for OPA12 and 25 for OPA13). Out of them, 9 bands were polymorphic with size ranged from $66 \mathrm{bp}$ to $1780 \mathrm{bp}$. The percentages of polymorphism were $21.74 \%$ (5/23) for OPO11, $16.67 \%$ $(2 / 12)$ for OPA12 and $8.0 \%(2 / 25)$ for OPA13. In case of cv. 'Festival', the three primers yielded a total of 59 bands with size ranged from $66 \mathrm{bp}$ to $1780 \mathrm{bp}$. Out of them, 15 bands were polymorphic (Table 4). The percentages of polymorphism were $41.67 \%(10 / 24)$ for OPO11, $16.67 \%(2 / 12)$ for OPA12, and $13.04 \%(3 / 23)$ for OPA13 (Table 5).

The obtained results of DNA analysis indicated that meristem-propagated plants constantly showed lowest percentage of polymorphism compared with direct- and callus-regenerated plants. The percentages of polymorphism for meristem-propagation method were $2.86 \%, 3.03 \%$ and $10.35 \%$ for cvs. 'Tudla', 'Galexia' and 'Festival', respectively with average of 5.41\% (Table 5). Unexpectedly, callus-derived plants showed lower percentage of polymorphism (16.18\%) compared with direct regeneration-derived plants (19.01\%) (Table 5). The percentages of polymorphism for callusregenerated plants were $11.77 \%, 0.00 \%$ and $30.77 \%$ for cvs. 'Tudla', 'Galexia' and 'Festival', respectively (Table $5)$. While the same percentages for direct regenerationderived plants were $15.15 \%, 28.57 \%$ and $13.3 \%$ for cvs. 'Tudla', 'Galexia' and 'Festival', respectively (Table 5).

Cv. 'Tudla' showed the lowest percentage of polymorphism $(9.93 \%)$ across the three propagation methods when compared with runner propagated plants with percentages of polymorphism as $2.86 \%, 15.15 \%$ and $11.77 \%$ for meristem, direct and callus propagation methods, respectively (Table 5). Similar percentages of polymorphism $(10.53 \%)$ across the three propagation methods when compared with runner propagated plants were observed in cv. 'Galexia' with percentages of polymorphism as $3.03 \%, 28.57 \%$ and $0.00 \%$ for meristem, direct and callus propagation methods, respectively (Table 5). The highest percentage of polymorphism (18.14\%) among the three cvs. was detected in cv. 'Festival' and the percentages were $10.35 \%, 13.3 \%$ and $30.77 \%$ for meristem, direct and callus propagation methods, respectively (Table 5). 


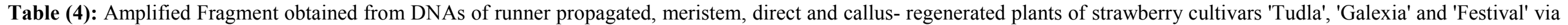
RAPD-PCR.

\begin{tabular}{|c|c|c|c|c|c|c|c|c|c|c|c|c|c|c|c|}
\hline \multirow{3}{*}{$\begin{array}{l}\text { Cultivar } \\
\text { Primer }\end{array}$} & \multicolumn{5}{|c|}{ Tudla } & \multicolumn{5}{|c|}{ Galexia } & \multicolumn{5}{|c|}{ Festival } \\
\hline & \multirow{2}{*}{$\begin{array}{l}\text { Band } \\
\text { Size } \\
\end{array}$} & \multicolumn{4}{|c|}{ Propagation Method } & \multirow{2}{*}{$\begin{array}{l}\text { Band } \\
\text { Size }\end{array}$} & \multicolumn{4}{|c|}{ Propagation Method } & \multirow{2}{*}{$\begin{array}{l}\text { Band } \\
\text { Size }\end{array}$} & \multicolumn{4}{|c|}{ Propagation Method } \\
\hline & & RP* & M & D & $\mathbf{C}$ & & RP* & $\mathbf{M}$ & D & $\mathbf{C}$ & & RP* & $\mathbf{M}$ & $\mathbf{D}$ & $\mathbf{C}$ \\
\hline \multirow{8}{*}{ OPO11 } & 1780 & 1 & 1 & 1 & 1 & 1780 & 1 & 1 & 0 & 1 & 1780 & 1 & 1 & 1 & 1 \\
\hline & 1158 & 0 & 1 & 1 & 1 & 1158 & 1 & 1 & 0 & 1 & 1104 & 0 & 1 & 1 & 0 \\
\hline & 849 & 1 & 1 & 1 & 1 & 924 & 1 & 1 & 1 & 1 & 849 & 1 & 1 & 1 & 1 \\
\hline & 616 & 1 & 1 & 1 & 1 & 600 & 1 & 1 & 0 & 1 & 649 & 0 & 1 & 1 & 1 \\
\hline & 427 & 1 & 1 & 1 & 1 & 400 & 1 & 1 & 0 & 1 & 400 & 1 & 1 & 1 & 1 \\
\hline & 332 & 1 & 1 & 0 & 1 & 289 & 1 & 1 & 1 & 1 & 300 & 0 & 0 & 0 & 1 \\
\hline & 239 & 1 & 1 & 1 & 1 & 219 & 1 & 1 & 0 & 1 & 259 & 1 & 1 & 1 & 0 \\
\hline & - & - & - & - & - & - & - & - & - & - & 219 & 0 & 1 & 1 & 1 \\
\hline \multirow[t]{2}{*}{ Total } & - & 6 & 7 & 6 & 7 & - & 7 & 7 & 2 & 7 & - & 4 & 7 & 7 & 6 \\
\hline & & & $1 / 13$ & $2 / 12$ & $1 / 13$ & & & $0 / 14$ & $5 / 9$ & $0 / 14$ & & & $3 / 11$ & $3 / 11$ & $4 / 10$ \\
\hline \multirow[t]{4}{*}{ OPA12 } & 412 & 1 & 1 & 1 & 1 & 384 & 1 & 1 & 1 & 1 & 406 & 1 & 1 & 1 & 1 \\
\hline & 311 & 1 & 1 & 1 & 1 & 239 & 1 & 1 & 1 & 1 & 305 & 1 & 1 & 1 & 1 \\
\hline & 100 & 1 & 1 & 0 & 0 & 83 & 1 & 1 & 0 & 1 & 100 & 1 & 1 & 1 & 0 \\
\hline & 83 & 0 & 0 & 1 & 1 & 66 & 0 & 0 & 1 & 0 & 66 & 0 & 0 & 0 & 1 \\
\hline \multirow[t]{2}{*}{ Total } & - & 3 & 3 & 3 & 3 & - & 3 & 3 & 3 & 3 & - & 3 & 3 & 3 & 3 \\
\hline & & & $0 / 6$ & $2 / 6$ & $2 / 6$ & & & $0 / 6$ & $2 / 6$ & $0 / 6$ & & & $0 / 6$ & $0 / 6$ & $2 / 6$ \\
\hline \multirow[t]{8}{*}{ OPA13 } & 1458 & 1 & 1 & 1 & 1 & 1500 & 1 & 0 & 0 & 1 & 1376 & 0 & 0 & 1 & 0 \\
\hline & 1257 & 1 & 1 & 0 & 1 & 1219 & 1 & 1 & 1 & 1 & 1181 & 1 & 1 & 1 & 0 \\
\hline & 1140 & 1 & 1 & 1 & 0 & 949 & 1 & 1 & 1 & 1 & 974 & 1 & 1 & 1 & 1 \\
\hline & 924 & 1 & 1 & 1 & 1 & 800 & 1 & 1 & 1 & 1 & 800 & 1 & 1 & 1 & 1 \\
\hline & 749 & 1 & 1 & 1 & 1 & 600 & 1 & 1 & 1 & 1 & 600 & 1 & 1 & 1 & 0 \\
\hline & 600 & 1 & 1 & 1 & 1 & 400 & 1 & 1 & 1 & 1 & 400 & 1 & 1 & 1 & 1 \\
\hline & 400 & 1 & 1 & 1 & 1 & 287 & 1 & 1 & 1 & 1 & 300 & 1 & 1 & 1 & 1 \\
\hline & 274 & 1 & 1 & 1 & 1 & - & - & - & - & - & - & - & - & - & - \\
\hline \multirow[t]{3}{*}{ Total } & & 8 & 8 & 7 & 7 & & 7 & 6 & 6 & 6 & & 6 & 6 & 7 & 4 \\
\hline & & & $0 / 16$ & $1 / 15$ & $1 / 15$ & & & $1 / 13$ & $1 / 13$ & $0 / 13$ & & & $0 / 12$ & $1 / 13$ & $2 / 10$ \\
\hline & & & $1 / 35$ & $5 / 33$ & $4 / 34$ & & & $1 / 33$ & $8 / 28$ & $0 / 33$ & & & $3 / 29$ & $4 / 30$ & $8 / 26$ \\
\hline$\%$ & & & 2.86 & 15.15 & 11.77 & & & 3.03 & 28.57 & 0.00 & & & 10.35 & 13.33 & 30.77 \\
\hline
\end{tabular}

* $\mathrm{RP}=$ Runner-Propagated, $\mathrm{M}=$ Meristem, $\mathrm{C}=$ Callus-derived plants and $\mathrm{D}=$ Direct. 
Table (5): Primers tested for their effectiveness in the RAPD-PCR analysis that produced polymorphic bands in different propagation methods compared with runner plants in three strawberry cultivars (Tudla, Galexia and Festival)

\begin{tabular}{|c|c|c|c|c|c|}
\hline \multirow[b]{2}{*}{$\begin{array}{c}\text { Propagation } \\
\text { Method }\end{array}$} & \multirow[b]{2}{*}{ Primer } & \multicolumn{4}{|c|}{ Bands } \\
\hline & & Total & Polymorphic & $\begin{array}{l}\text { Size of Polymorphic } \\
\text { Bands (bp) }\end{array}$ & Polymorphic \%* \\
\hline & & & Tudla & & \\
\hline \multirow[t]{3}{*}{ Meristem } & OPO11 & 13 & 1 & 1158 & \multirow{3}{*}{2.86} \\
\hline & OPA12 & 6 & 0 & - & \\
\hline & OPA13 & 16 & 0 & - & \\
\hline \multirow[t]{3}{*}{ Direct } & OPO11 & 12 & 2 & 1158,332 & \multirow{3}{*}{15.15} \\
\hline & OPA12 & 6 & 2 & 100,83 & \\
\hline & OPA13 & 15 & 1 & 1257 & \\
\hline \multirow[t]{3}{*}{ Callus } & OPO11 & 13 & 1 & 1158 & \multirow{3}{*}{11.77} \\
\hline & OPA12 & 6 & 2 & 100,83 & \\
\hline & OPA13 & 15 & 1 & 1140 & \\
\hline \multicolumn{6}{|c|}{ Galexia } \\
\hline \multirow[t]{3}{*}{ Meristem } & OPO11 & 14 & 0 & - & \multirow{3}{*}{3.03} \\
\hline & OPA12 & 6 & 0 & - & \\
\hline & OPA13 & 13 & 1 & 1500 & \\
\hline \multirow[t]{3}{*}{ Direct } & OPO11 & 9 & 5 & $1780,1158,600,400,219$ & \multirow{3}{*}{28.57} \\
\hline & OPA12 & 6 & 2 & 83,66 & \\
\hline & OPA13 & 13 & 1 & 1500 & \\
\hline \multirow[t]{3}{*}{ Callus } & OPO11 & 14 & 0 & - & \multirow{3}{*}{0.00} \\
\hline & OPA12 & 6 & 0 & - & \\
\hline & OPA13 & 13 & 0 & 1500 & \\
\hline \multicolumn{6}{|c|}{ Festival } \\
\hline \multirow[t]{3}{*}{ Meristem } & OPO11 & 11 & 3 & $1104,649,219$ & \multirow{3}{*}{10.35} \\
\hline & OPA12 & 6 & 0 & - & \\
\hline & OPA13 & 12 & 0 & - & \\
\hline \multirow[t]{3}{*}{ Direct } & OPO11 & 11 & 3 & $1104,649,219$ & \multirow{3}{*}{13.3} \\
\hline & OPA12 & 6 & 0 & - & \\
\hline & OPA13 & 13 & 1 & 1376 & \\
\hline \multirow[t]{3}{*}{ Callus } & OPO11 & 10 & 4 & $649,300,259,219$ & \multirow{3}{*}{30.77} \\
\hline & OPA12 & 6 & 2 & 100,66 & \\
\hline & OPA13 & 10 & 2 & 1181,600 & \\
\hline
\end{tabular}

*Average of the three primers used in each propagation method 


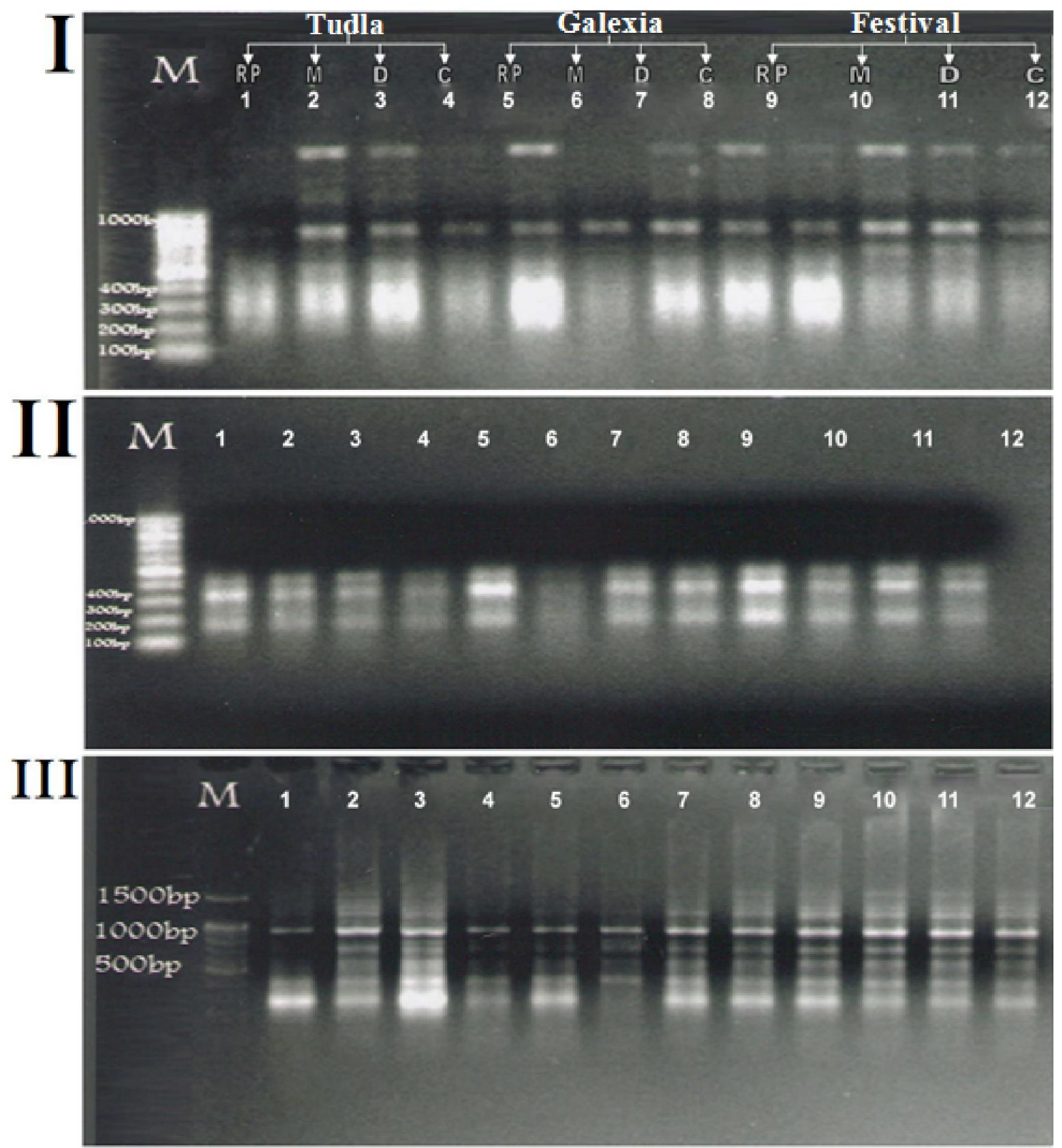

Figure (1): Agarose gel showing Random Amplified Polymorphic DNA amplification profile of strawberry cvs. derived from different propagation methods analyzed with primers OPO11 (I), OPA12 (II), OPA13 (III). M: 1kb markers, lanes 1, 2, 3, 4 for cv. 'Tudla'; 5, 6, 7, 8 for cv. 'Galexia' and 9, 10, 11, 12 for cv. 'Festival'. Lanes 1, 5, 9 for runner plants; 2, 6,10 for meristem derived plants; 3, 7, 11 for direct regenerated plants and 4, 8, 12 for callus regenerated plants.

\section{DISCUSSION}

Traditionally, strawberry plants are propagated by runners derived from nuclear stock materials via shoot tip culture in vitro. Alternatively, plants could be obtained indirectly via callus phase or directly from leaf discs (Mohamed et al., 2007). Both in vitro propagation systems allows the production of variant plants, of which, some might show unique characteristics as new somaclones. Thus, plants derived from these propagation systems were tested for their ex vitro performance and genetic stability.

Tissue culture- propagated mother plants of strawberry and their daughter plants often produce more runners in the planting year as well as in the subsequent year (Cameron and Hancock, 1986; Swartz et al., 1981). The runnering behavior observed in this investigation is consistent with the typical response of in vitropropagated strawberries reported in the literatures. The increased runner production of in vitro propagated plants is believed to be due to enhanced axillary bud activity caused by the carry over effect of cytokinin in the shoot proliferation medium (Waithaka et al., 1980). However, different reaction of cultivars to enhanced runner production of tissue culture propagated plants was observed by Szczygiel and Borkowska, 1997; Nehra et al., 1994; Karhu and Hakala, 2002). Our results are in agreement with the previous reports as the tested cultivars in this experiment varied in their response to runner production. This may be explained by the uneven build up of cytokinin in the tissue culture plants of different genotypes which may affect the axillary bud activity and subsequent production of runners. The superior vigor observed with tissue 
culture-propagated over conventionally propagated strawberry can be expected due to higher rates of $\mathrm{CO}_{2}$ assimilation and stomatal conductance in micropropagated plants compared to runner-propagated plants (Cameron et al., 1989).

In strawberry, the process of plant regeneration from callus is often associated with more somaclonal variation than other modes of regeneration. The occurrence of polyploidy and aneuploid changes in long-term callus cultures of strawberry has been reported (Nehra et al., 1991, 1992). Additionally, some of the cytological abnormalities observed in long-term callus cultures are passed onto regenerants from such cultures (Nehra et al., 1992; Popescu et al., 1997).

The presence of disorganized growth phase in tissue culture is considered as a major feature that cause somaclonal variation (Rani and Raina, 2000). Tissue culture systems subject to instability and disorganized growth (non-meristem explant culture) demonstrated that cellular organization is a critical feature and that somaclonal variation is related to disorganized growth. Generally, the more the organizational structure of the plant is broken down, the greater the chance of mutations occurring. As a consequence, highly differentiated tissues (roots, leaves, stems) generally produce more variants than explants from axillary buds and shoots tips that have pre-existing meristems (Bairu et al., 2011). This study has confirmed the effect of propagation method on genetic stability since the variation was higher among regenerated plants obtained from leaf explants compared to meristem and runner propagated plants. This might be explained by the initial heterogeneity of leaf tissue (epidermis, mesophyll, and parenchyma). Morozova (2002) reported a 9\% abnormal leaf morphology of meristem-micropropagated plants while the percentage increased to $21 \%$ in plants regenerated from leaf explants of Fragaria vesca. In melon, the explants from the apical meristem produced fewer or no tetraploid plants when compared with other explants from the cotyledon tissue, confirming that adventitious shoot formation allows somaclonal variation while axillary branching maintains genetic stability (Adelberg et al., 1994). The American strawberry genetic resource collection (USDA) stored in vitro plants on plant growth regulators-free medium at $4^{\circ} \mathrm{C}$ for 4 years and were tested for somaclonal variation (Reed and Hummer, 2002). No differences were detected based on RAPD markers or in observation of specific morphological traits. The major reason for such stability is that the procedures produced plants from pre-existing meristematic tissues and stable genotypes and avoid callus proliferation. The result of RAPD in current investigation indicated genetic stability of plants derived from meristem tip explants. Similar results have been reported (Mohamed, 2007). DNA variation induced from in vitro culture of strawberry was found to be lost after transferring the plants to the greenhouse which suggests the epigenetic nature of tissue cultureinduced variation (Brandizzi et al., 2001).

Our results suggested that plants regenerated from callus of the specific cultivar 'Festival' showed a relative instability compared to other genotypes. RAPD has been successfully used to detect tissue culture induced variation (somaclonal variants) in tomato (Soniya et al., 2001), in garlic (Al-Zahim et al., 1999) and in almond (Martins et al., 2004). In strawberry, we used RAPD to characterize the polymorphic phenotypic plants. Polymorphic banding pattern was observed with three primers. This confirmed that variation observed in callus-regenerated plants were genetic. In current study using 10 RAPD primers, little polymorphism was detected among the plants regenerated starting from meristems or leaf discs. Similar results in strawberry have been described previously by Nehra et al. (1994) and Sutan et al. (2009). This confirms the previous assumption that most somaclonal variations occur in plants regenerated from in vitro cultures that have undergone as dedifferentiation phase (Larkin and Scowcroft, 1981). Also, confirm that the enhanced axillary branching culture generally considered being an in vitro culture system with low risk of genetic instability.

The DNA amplification products could result from changes in either the sequence of the primer binding sites or changes which alter the size that result in the successful amplification of target DNA (Rani et al., 1995). In our study, the amplification products exhibited monomorphism among micropropagated strawberry plants derived from meristem or direct shoot regeneration and were similar to those derived from standard runner plants. Since there were little changes in banding patterns observed in tissue culture plants (from meristem or direct shoot regeneration) compared with that of the standard runner plants, we can conclude that micropropagation system that utilizes either meristem tip culture or direct shoot regeneration can be followed without much risk of genetic instability in some genotypes (as in the case of cv. 'Tudla'). In addition the lack of polymorphic bands among the RAPD profiles of plants regenerated through organogenesis can be associated with higher genetic stability in used genotypes. However, in other genotype 'Festival', callus-derived plants had the highest polymorphism and may represent a new somaclone. The results obtained in this investigation confirmed the usefulness and applicability of RAPD method in determining genetic stability and uniformity of plants clonally propagated in vitro as well as detecting and identifying the somaclonal variants, which might be used further in breeding programs.

\section{REFERENCES}

Adelberg, J. W., B. B. Rhodes, H. T. Skorupska and W. C. Bridges (1994). Explant origin affects the frequency of tetraploid plants from tissue cultures of melon. HortScience, 29(6): 689692.

Al-Zahim, M. A., B. V. Ford-Lloyd and H. J. Newbury (1999). Detection of somaclonal variation in garlic (Allium sativum L.) using RAPD and cytological analysis. Plant Cell Reports, 18(6): 473-477.

Bairu, M. W., A. O. Aremu and J. Van Staden (2011). Somaclonal variation in plants: causes and 
detection methods. Plant Growth Regulation, 63(2): 147-173.

Bernardo Royo, J. and R. Itoiz (2004). Evaluation of the discriminance capacity of RAPD, isoenzymes and morphologic markers in apple (Malus $\times$ domestica Borkh.) and the congruence among classifications. Genet.Resour. Crop Evol., 51: 153-160.

Biswas, M. K., M. Dutt, U. K. Roy, R. Islam and M. Hossain (2009). Development and evaluation of in vitro somaclonal variation in strawberry for improved horticultural traits. Scientia Horticulturae, 122(3): 409-416.

Boxus, P. H. (1974). The production of strawberry plants by in vitro micropropagation. J. Hortic. Sci., 49: 209-210.

Boxus, P. H., M. Ouoirin and J. M. Laine (1977). Large scale propagation of strawberry plants from tissue culture. pp. 130-143. In: J. Reinert and Y.P.S. Bajaj (Eds.). Applied and fundamental aspects of plant cell, tissue and organ culture. Springer-Verlag, New York.

Boxus, P. H., A. Jemmali, J. M. Terzi and O. Arezki (2000). Drift in genetic stability in micropropagation: the case of strawberry. Acta Hort., 530: 155-162.

Brandizzi, F., C. Forni, A. Frattarelli and C. Damiano (2001). Comparative analysis of DNA nuclear content by flow cytometry on strawberry plants propagated via runners and regenerated from meristem and callus cultures. Plant Biosystems, 135: 169-174.

Cameron, J. S., J. F. Hancock and T. M. Nourse (1985). The field performance of strawberry nursery stock produced originally from runners or micropropagation. Adv. Strawberry Prod., 4: 56-58.

Cameron, J. S. and J. F. Hancock (1986). Enhanced vigor in vegetative progeny of micropropagated strawberry plants. HortScience, 21: 1225-1226.

Cameron, J. S., J. F. Hancock and J. A. Flores (1989). The influence of micropropagation on yield components, dry matter partitioning and gas exchange characteristics of strawberry. Scientia Horticulturae, 38: 61-67.

Cloutier, S. and B. Landry (1994). Molecular markers applied to plant tissue culture. In Vitro Cell Dev. Biol- Plant, 30: 32-39.

Debnath, S. C. (2009). Characteristics of strawberry plants propagated by in vitro bioreactor culture and ex vitro propagation method. Engineering in Life Sciences, 9(3): 239-246.

Evans, D. A., W. R. Sharp and H. P. Medina-Filho (1984). Somaclonal and gametoclonal variation. Am. J. Bot., 71: 759-774.

Evans, D. A. (1989). Somaclonal variation-genetic basis and breeding applications. Trends in Genetics, 5: 46-50.

FAOSTAT (2015). http://www.fao.org.

Gaafar, R. M. and M. M. Saker (2006). Monitoring of cultivars identity and genetic stability in strawberry varieties grown in Egypt. World Journal of Agricultural Sciences, 2(1): 29-36.

Gantait, S., N. Mandal and P. K. Das (2010). Field performance and molecular evaluation of micropropagated strawberry. Recent Res. Sci. Technol., 2: 12-16.

Gostimsky, S. A., Z. G. Kokaeva and F. A. Konovalov (2005). Studying plant genome variation using molecular markers. Russ. J. Genet., 41:378388.

Haque, M. S. (2013). Assessment of field performance and molecular characterization of tissue culture variants of strawberry. M. Sc. Thesis. Bangladesh Agricultural University, Bangladesh.

Karhu, S. and K. Hakala (2002). Micropropagated strawberries on the field. Acta Hort., 567: 321324.

Kartha, K. K., L. Leung and K. Pahl (1980). Cryopreservation of strawberry meristems and mass propagation of plantlets. J. Am. Soc. Hort. Sci., 105(4): 481-484.

Kumar, M. B., R. E. Barker and B. M. Reed (1999). Morphological and molecular analysis of genetic stability in micropropagated Fragaria $x$ Ananassa cv. Pocahontas. In Vitro Cell and Dev. Biol.-Plant., 35(3): 254-258.

Larkin, P. J. and W. R. Scowcroft (1981). Somaclonal variation- a novel source of variability from cell cultures for plant improvement. Theoretical and Applied Genetics, 60(4): $197-$ 214.

Litwińczuk, W. (2004). Field performance of 'Senga Sengana' strawberry plants (Fragaria $\times$ ananassa Duch.) obtained by runners and in vitro through axillary and adventitious shoots. Electronic Journal of Polish agricultural Universities, Horticulture, 7(1).

Marcotrigiano, M., H. J. Swartz, S. E. Gray, D. Tokarcik and J. Popenoe (1984). The effect of benzylamino purine on the in vitro multiplication rate and subsequent field performance of tissue-cultured strawberry plants. Adv. Strawberry Prod., 3: 23-25.

Martins, M., D. Sarmento and M. M. Oliveira (2004). Genetic stability of micropropagated almond plantlets, as assessed by RAPD and ISSR markers. Plant Cell Reports, 23(7): 492-496.

Mohamed, A. E. (2007). Somaclonal variation in micropropagated strawberry detected at the molecular level. International Journal of Agriculture and Biology, 9(5): 721-725.

Mohamed, F., H. J. Swartz and J. G. Buta (1991). The role of abscisic acid and plant growth regulators in tissue culture-induced rejuvenation of strawberry ex vitro. Plant Cell, Tissue and Organ Culture, 25(1): 75-84.

Mohamed, F. H., M. S. Beltagi, M. A. Ismail and G. F. Omar (2007). High frequency, direct shoot regeneration from greenhouse-derived leaf disks of six strawberry cultivars. Pakistan Journal of Biological Sciences, 10(1): 96-101. 
Mohamed, F. H., K. E. Abd El-Hamed, F. A. Omar and A. A. El- Shahat (2013). The potential of in vitro organogenesis in different strawberry genotypes. Hortscience Journal of Suez Canal University, 1: 115-126.

Murashige, T. and F. Skoog (1962). A revised medium for rapid growth and bioassays with tobacco tissue culture. Physiol. Plant., 15: 473-497.

Morozova, T. (2002). Genetic stability of pure lines of FragariavescaL. in micropropagation and long-term storage in vitro.ActaHort, 567: 8587.

Murray, M. G. and W. F. Thompson (1980). Rapid isolation of high molecular weight plant DNA. Nucleic Acids Res., 8: 4321-4325.

Nadig, S. G., K. L. Lee and S. M. Adams (1998). Evaluating alterations of genetic diversity in sunfish populations exposed to contaminants using RAPD assay. Aquatic toxicology, 43(2): 163-178.

Nehra, N. S., C. Stushnoff and K. K. Kartha (1989). Direct shoot regeneration from strawberry leaf disks. J. Am. Soc. Hort. Sci., 114: 1014-1018.

Nehra, N. S., K. K. Kartha and C. Stushnoff (1991). Isozymes as markers for identification of tissue culture and greenhouse-grown strawberry cultivars. Canadian Journal of Plant Science, 71(4): 1195-1201.

Nehra N. S., K. K. Kartha, C. Stushnoff and K. L. Giles (1992). The influence of plant growth regulator concentrations and callus age on somaclonal variation in callus culture regenerants of strawberry. Plant Cell, Tissue and Organ Culture, 29: 257-268.

Nehra, N. S., K. K. Kartha, C. Stushnoff and K. L. Giles (1994). Effect of in vitro propagation methods on field performance of two strawberry cultivars. Euphytica, 76(1): 107-115.

Piola, F., R. Rohr and P. Heizmann (1999). Rapid detection of genetic variation within and among in vitro propagated cedar (Cedruslibani Loudon) clones. Plant Sci., 141: 159-163.

Popescu, A. N., V. S. Isac and M. S. R. Coman (1997). Somaclonal variation in plants regenerated by organogenesis from callus cultures of strawberry (Fragaria $\times$ ananassa). Acta Hort., 439: 89-96.

Rani, V., A. Parida and S. N. Raina (1995). Random amplified polymorphic DNA (RAPD) markers for genetic analysis in micropropagated plants of Populusdeltoides Marsh. Plant Cell Reports, 14(7): 459-462.

Rani, V. and S. N. Raina (2000). Genetic fidelity of organized meristem-derived micropropagated plants: a critical reappraisal. In Vitro Cell Dev. Biol.-Plant, 36: 319-330.

Reed, B. M. and K. E. Hummer (2002). Cryopreservation of Ribes. In Cryopreservation of Plant Germplasm II (pp. 323-343). Springer Berlin Heidelberg.

Sen, S. and V. Dhawan (2010). Molecular analysis of micropropagated strawberry plants using ISSR (Inter Simple Sequence Repeats) markers for ascertaining clonal fidelity. Acta Hort., 865: 345-348

Sharma, N. K. and M. Kumar (2012). EST SSR markers analysis of in vitro regenerated plantlets of Festival and Sweet Charlie cultivars of strawberry. International Journal of Agriculture, Environment and Biotechnology, 5(4): 315-322.

Soniya, E. V., N. S. Banerjee and M. R. Das (2001). Genetic analysis of somaclonal variation among callus-derived plants of tomato. Current Science-Bangalore, 80(9): 1213-1215.

Steel, R. G. and J. H. Torrie (1980). Principles and Procedures of Statistics: A Biometrical Approach. McGraw-Hill, New York, NY, USA.

Sutan, A. N., A. Popescu, R. Gheorghe, C. F. Popescu and V. Isac (2009). In vitro micropropagation of ornamental strawberry cv. "Serenata" and the assessment of genetic stability by RAPD markers. Annals of the University of CraiovaAgriculture, Montanology, Cadastre Series, 39(2): 366-372.

Swartz, H. J., G. J. Galletta and R. H. Zimmerman (1981). Field performance and phenotypic stability of tissue culture-propagated strawberries. J. Am. Soc. Hort. Sci., 106: 667673.

Szczygiel, A. and B. Borkowska (1997). Field evaluation of micropropagated strawberry plants as related to different rooting and nutritional methods. Acta Hort., 439: 347-351.

Szczygiel, A., K. Pierzga and B. Borkowska (2002). Performance of micropropagated strawberry plantlets after planting in the field. Acta Hort., 567: 317-320.

Venkatachalam, L., R. V. Sreedhar and N. Bhagyalakshmi (2008). The use of genetic markers for detecting DNA polymorphism, genotype identification and phylogenetic relationships among banana cultivars. Mol. Phylogenet. Evol., 47: 974-985.

Waithaka, K., A. C. Hildebrandt and M. N. Dana (1980). Hormonal control of strawberry axillary bud development in vitro. J. Am. Soc. Hort. Sci., 105: 428-430. 


\section{السلوك الحقلي والثبات الوراثى لنباتات الفراولة الناتجة من طرق إكثار معملية مختلفة \\ فؤاد حسن محمد، خالد السيد عبد الحميد، فاروق عبد العزيز عمر، عبد الله على الشحات

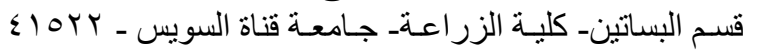

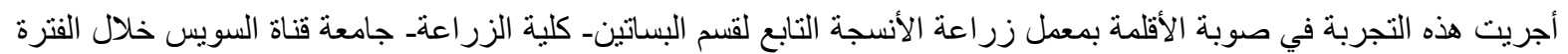

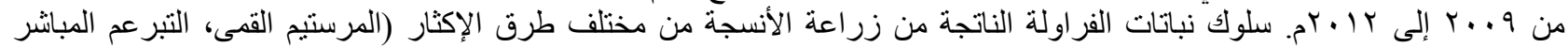

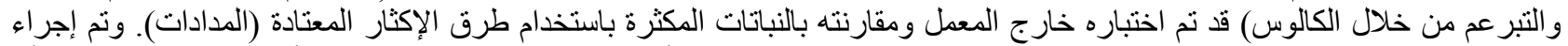

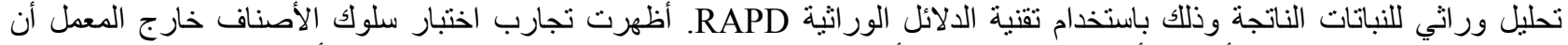

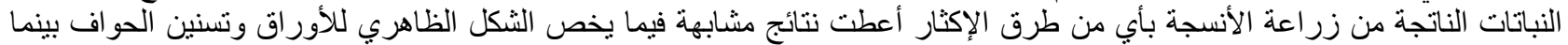

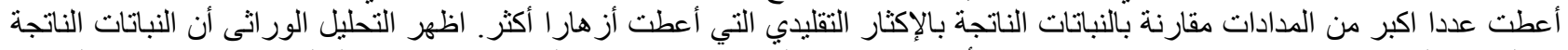

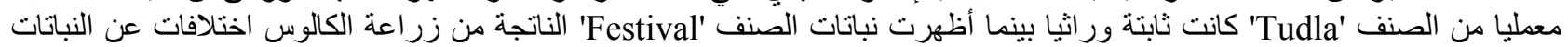

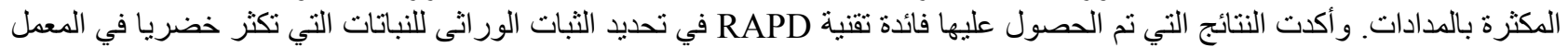
وكذلك الكثف عن الاختلافات الجسدية والتي يمكن استخدامها في بر امج التربية. 